Article

\title{
Singapore and Sydney: Regulation and Market-Making
}

\author{
Ching Leong and Lili $\mathrm{Li}$ * \\ Institute of Water Policy, Lee Kuan Yew School of Public Policy, National University of Singapore, 469C Bukit \\ Timah Road, 259772 Singapore, Singapore; ching@nus.edu.sg \\ * Correspondence: li.lili89@u.nus.edu; Tel.: +65-9132-8622
}

Received: 9 March 2017; Accepted: 12 June 2017; Published: 15 June 2017

\begin{abstract}
The different institutional forms of water utilities of Singapore and Sydney provide an interesting natural experiment on the role of a regulator in government-owned utilities (GOUs). In both cities, water is provided by GOUs. In Sydney, however, there is an independent regulator whereas in Singapore the Public Utilities Board is a statutory board without a regulator. This paper compared the regulation and market-making efforts by water utilities of Singapore and Sydney. We find that both are similar in quality of service, operational and economic efficiencies, and private sector investments. The difference lies in their choice of the instrument for involving the private sector. Sydney does this by appointing a specific regulator whereas Singapore uses contracts. Indeed, it argues that the government-owned water utilities of both Sydney and Singapore seek to capture as many benefits as possible from market-making efforts, that is, from mimicking private sector behaviors and by operating from the basic tenets of the regulatory state. Both countries seek to make rules addressing the "market failure" of a monopoly. In Sydney, such efforts are seen in the explicit contestability of the market and the high engagement with customers whereas in Singapore the efforts are more muted on both counts and are instead motivated toward developing water businesses as a whole.
\end{abstract}

Keywords: regulation; market-making; water utilities; Singapore; Sydney

\section{Introduction}

The case for intervention in government-owned utilities (GOUs) has often been made based on two arguments-the first empirical and the second theoretical. First, GOUs are pervasively poor performing. As estimated, about 48,000 million $\mathrm{m}^{3}$ of potable water were lost as non-revenue water every year in the world through leaks, theft, and operational inefficiencies, while at least $50 \%$ of these losses happened in developing countries where GOUs were struggling to earn more revenue for maintenance and expansion of services [1]. Komives et al. [2] pointed out that only $30 \%$ of utilities globally and $50 \%$ of those in developed countries generated sufficient revenues to cover operation, maintenance, and particular capital costs. The quick conclusion from this is to focus on the need for private sector participation. Lots of literature has investigated the impact of private sector participation on the performance of utilities, but the conclusions are diverse. Some empirical studies found that private sector participation improved performance regarding a range of indicators, such as quality of services, productivity, and labor management [3-8]. However, other studies found that GOUs were superior with higher technical efficiency [9] or better financial shape and more investments [10]. A few of those studies that claimed private operators to be more efficient also pointed out that GOUs seemed to be less debt-dependent [11]. Nevertheless, Suárez-Varela et al. [5] summarized that a large volume of empirical studies, such as Hon et al. [12] and Estache et al. [13], found little correlation between the ownership and efficiency in the provision of water services. Given these, while there was 
some correlation between GOUs and poor performance, it does not appear to be empirically true that ownership structure causes operational weakness.

This is related to the second argument for intervention-that of market failure. Given the monopolistic nature of water infrastructure, government interventions are thought to be necessary to prevent abuse of monopolistic power. While the temptation to profiteer may be thought to exist most strongly in private organizations, regulatory oversight is thought to be necessary for GOUs as well. As Vinnari [14] (p. 164) points out, "although managers of public-owned utilities are usually perceived to act in the public interest, it is also possible that they are self-interested budget-maximizers who might not have their customers' best interests at heart". This issue is sometimes analyzed in public administration literature as the "principal-agent" problem. That is to say, GOUs are thought to present a weak set of incentives for water managers to capture efficiencies since public-sector managers are assumed to act in their self-interests that are not necessarily consistent with the utility's goals [15]. This seems, however, to be an easy fix regarding aligning incentives and there is very limited empirical evidence to suggest that public sector bureaucrats do behave in this manner [16,17]. Therefore, this notion of "market failure" does not appear to hold in general [18].

Ownership structure per se, therefore does not appear to determine outcomes. Rather, the question here is whether the operator, private or public, can hold the right qualities for the enterprise to succeed. The need for regulating GOUs, therefore, stems from a perceived demand for the "protection of the public interest" [7] (p. 97), given its natural monopoly [19], which attracts complacency or rent-seeking behavior.

Usually, regulation comes in the form of carrots and sticks. An example can be water regulators "incentivizing improved service quality by means of awards or penalties when setting prices" [7] (p. 98). On the other hand, performance standards can be enforced by imposing audits, fines and penalties [7].

Such carrots and sticks have been instantiated in various ways including sector-specific or multi-sector national regulators, contract monitors, and municipal councils or agencies [20]. In addition, these actors are important in translating the regulatory models in contingencies [21,22]. The dominant form of regulation tends to be economic regulation, for instance through open and "competitive tendering procedures" [23] (p. 674) when the government outsources utility services to the private sector or engages in public-private partnerships (PPPs).

It is necessary for regulation to "mitigate perceived biases and proclivities of the public sector" [24] (p. 164) which may result in unfair competition. In the case of a monopoly where competition is absent, economic regulation checks the tendencies of over-investment and overpricing by "imposing performance standards" [24] (p. 155). Particularly in governance, regulation "[depoliticizes] rates, which in turn builds public trust as well as investor and creditor confidence" [24] (p. 164).

Berg and Marques conducted a literature review of 190 quantitative studies and concluded that "regulation has improved the efficiency and productivity of water utilities" [25] (p. 603), with particular effectiveness when using incentive regulation. Berg points out that economic sanctions are ineffective for GOUs as they further contribute to inefficiency [20]. Essentially, effective regulators require "appropriate legal authority and funding," leadership that is independent of the government, clear objectives, and an incentive-based system [20] (p. 30). Many regulators who meet these requirements have seen positive impacts on GOUs, from the Netherlands to Uganda, to Phnom Penh in Cambodia, and Scotland [20]. While regulators can be beneficial in ensuring accountability and efficiency of GOUs, they need to be accompanied by other institutional factors [20].

Our hypothesis is that regulation has a significant role to play in addressing these vulnerabilities. Just as the first wave of optimism in the use of private operators as a panacea for poorly performing water utilities, the same cautionary tale can be told by the current dissembling of private partnerships. Here, we find that internal factors such as corporate governance, as well as financial and operational management, are key factors in obtaining the key legitimation elements of the regulatory state. These have less to do with whether the operators are private or public than with more specific considerations such as governance practices and operational and financial guidelines. The next section of the paper will elaborate on these arguments. 


\section{Literature Review: Rethinking Regulation of Water Utilities}

The rise of the regulatory state in the water sector was embedded within the need to gain private investments and public trust. Estimates show that developing countries would need USD 42,000 million to meet the water supply component of the Millennium Development Goals, while for sanitation it is USD 142,000 million [26]. Given these figures, it is unlikely that governments in developing countries would be able to finance water infrastructure on their own. In fact, some estimated $23 \%$ of the world's population was served to some extent by the private sector in 2015, compared to $7 \%$ in 2009 [27]. The participation of the private sector is not only an economic necessity [28]. Because water is essential to life, the mobilization of private investments in this sector is seen not just as fiscally prudent but a matter of political obligation. Bremer states that, "If mobilization of private investment is the only way that water systems can be put in place to meet community needs, then governments have a duty to do precisely that. The question is not whether this option makes sense-it is the only option" [29] (p. 11).

Market failure is often attributed to the perceived clash of public interests with the profit motive of the private operators [30]. More profoundly, there is a perceived conflict between the right to water and the profit motive [31]. Such tensions have given rise to public hostility and as a consequence, a cooling of enthusiasm for and by private investors in the water sector [32]. More work has been done recently $[33,34]$ to rethink the governance of water resources. While market building measures and private sector participation had been "touted as panaceas for water supply and sanitation" in the past [33] (p. 89), such justifications have worn thin. In effect, water privatization under this market-building lens has already "peaked." In its place, other priorities such as social equity, environment, and public health are increasingly coming to the fore.

We align ourselves with this rethinking of market-making efforts. Our hypothesis is that ownership per se is not determining successful public utilities. Rather, it is issues such as financial and operational management and corporate governance that impact the three key elements of the regulatory foundations of privatization-capturing efficiencies, fiscal prudence, and credible commitment.

We investigate these issues under the lens of regulation, used to denote some form of governance, or efforts by the government to steer the economy, as well as in the wider sense, all forms of social control [35]. Market-making under a regulatory state aims to capture efficiencies, effectiveness, and a "service" culture, under which political ties are replaced by contracts between a consumer and service provider. The regulatory state is therefore concerned with the role of competition, markets, and the means of private sector participation [36].

One of the key elements of the regulatory state is the use of the market for public action, which is sometimes called "regulatory capitalism." The central tenet of regulatory capitalism is, on the face of it, a simple one. In the face of antipathy towards big government [37,38], the state has retreated and been replaced by third-party government technologies $[39,40]$, which include private sector participation [41]. While the primary accounts of the regulatory state have examined how regulations have guided private sector participation, our argument is such market-making efforts can be used equally on GOUs. This is the first way forward for GOUs—-to use regulations to capture private sector efficiencies while maintaining public ownership.

The second way forward is based on a techno-rational argument- that the management of utilities should be done by the experts and special agencies [37]. However, there is an explicit recognition that employees under the public and private sectors tend to be incentivized differently. Banfield points to the material incentives and profit-seeking nature of private companies, while in the public sector, non-material factors such as job security, participation in important affairs, and "power and glory" serve as principal incentives [42]. There is also a lack of competition in the public sector in contrasts to the private sector, which encourages innovation, efficiency, and cost-reducing measures. Additionally, public companies often answer to several agencies with different objectives, resulting in contradictory or weak incentives. Notwithstanding institutional factors, it is noteworthy that some personal incentives remain the same in both sectors, including power, status and improved promotional prospects, and salary [43]. Hence, regulations can provide strong incentives to GOUs 
employees while creating the market for competition. The experience of water privatization in Britain is a good case in point. In many cases, regulations created a market where none existed [44].

With the right set of regulations, therefore, GOUs can mimic operating in a private sector environment. As such, it can capture the private virtues of efficiency, innovation as well as the legitimation from being a publicly owned, non-profit driven entity. Such a balancing act appears to be harder for privately owned utilities to obtain, despite the best efforts of the regulator to do so. Bakker sees this as the failure of the regulatory model to "contain the contradictions between stable returns and the efficiency imperative, on the one hand, and politically acceptable rates of return and the equity imperative, on the other" [44] (p. 359). Those "contradictions" thus resulted in a "regulatory creep" in the industry in the 1990s [44] (p. 363).

In short, therefore, there are three main attractions for market-making within a GOU environment. First, market-making rules allow the GOUs to capture private sector efficiencies and lower costs. Second, regulations are less political than direct government and hence more credible. Third, they provide for the participation of more players in public affairs to fill in the gaps in information and knowledge of politicians and bureaucrats. Our next section sees how these market-making measures work out in two cases of GOUs.

\section{Two Cases: Sydney and Singapore}

\subsection{Sydney}

\subsubsection{Water Demand in Sydney}

Sydney is the capital city of New South Wales (NSW), located on the East coast of Australia. It is surrounded by Sydney Harbor and has relatively uniform rainfall throughout the year. According to the Australian Bureau of Statistics, Sydney has a population of 4.84 million in 2014 on a land area of $12,367.7 \mathrm{~km}^{2}$ [45]. Providing sufficient fresh water for its large population has been a persistent challenge for Sydney.

During early colonial times, Sydney faced frequent water shortages. To alleviate the water shortage problem, the Upper Nepean Scheme was built at the cost of USD 2.6 million (1880-1888) to transfer water from the Nepean, Cataract, and Cordeaux rivers into Sydney [46]. Further, four large dams, including the Cataract Dam, Cordeaux Dam, Avon, and Nepean Dam, were constructed from 1907 to 1935. By the 1940s however, the water shortage problem again became acute [46]. More dams were built between the 1930s and 1970s, including two major dams of Woronora and Warragamba; despite these efforts, the city still failed to manage the burgeoning demand from the rising population. The problem was further aggravated by severe water pollution. By 1997, the NSW government was facing an aging sewerage system with serious problems such as cracked pipes, poorly fitting inspection holes, and no direct connection of storm-water pipes to the sewerage system, which were causing the overflow of sewerage [47].

\subsubsection{Institutional Reform in the Water Sector}

The management of water utilities in Sydney has undergone drastic changes since the 1840s. From 1788, the British colonial government was responsible for the water supply, and the Sydney City Council took over the responsibility in 1842. In 1888, the Board of Water Supply and Sewerage was established to take charge of the property, powers, and obligations relating to water supply and sewerage service. This board was replaced by the Metropolitan Water Sewerage and Drainage Board in 1925 that was later reconstituted as the Water Board in 1987. In 1995, Sydney Water Corporation Limited (Sydney Water) succeeded the Water Board under the Sydney Water Act (SWA), and it has served the city till today.

Sydney Water is defined as a government-owned corporation responsible for water supply, water recycling, sewerage, and storm-water services in Sydney and its suburbs [48]. Its primary water sources 
are WaterNSW and the Sydney Desalination Plant (SDP). WaterNSW manages 21 dams including the Warragamba dam, while the Sydney Desalination Plant operates mainly in response to drought years. Till 2015, Sydney Water owned and ran 21,635 km length of drinking water mains, 25,085 km length of wastewater treatment mains and $685 \mathrm{~km}$ length of recycled water mains, and it also controlled $447 \mathrm{~km}$ length of storm-water channels. The board of Sydney Water consists of a chairperson and eight directors who are appointed by voting shareholders [49]. Sydney Water pays annual dividends to the NSW government and can seek funds from the government for additional costs incurred.

The Independent Pricing \& Regulatory Tribunal of NSW (IPART) serves as an independent regulator for Sydney Water and its competitors in the private sector. The government delegates to IPART the rights to regulate water pricing and audit the annual performance of water utilities (either public or private) in NSW. Objectives set for IPART in legislation broadly cover economic efficiency, market competition, consumer protection, commercial sustainability and financing, and environmental protection [50]. IPART has high statutory independence, but the government can influence IPART by writing directives on issues to be considered.

\subsubsection{IPART: The Independent Regulator}

Broadly speaking, IPART functions as an operating license administrator of water, gas, and electricity industries. IPART regulates Sydney Water by imposing rules on the operating license, which requires Sydney Water to meet certain service quality standards, environmental standards, and performance standards and requirements in the SWA and other applicable laws [51]. Sydney Water must also maintain an Environmental Management System consistent with Australian Standard AS/NZS ISO 14001:2004, and develop a Quality Management System consistent with the Australian Standard AS/NZS ISO 9001:2008 [52]. Further, Sydney Water has to make annual reports and financial disclosures publicly available to keep the public informed on how well the utilities are performing [53].

The other role of IPART is in regulating prices for water, transport, electricity, and gas industries. IPART was primarily established in 1992 to provide oversight of the pricing for these sectors. It was recognized that the water pricing was problematic [54] due to its highly politicized nature. Also, a significant component of calculating water charges was unfairly based on property-value charges, to the extent that Sydney Water received more than a third of its revenue from property-value based charges in 1993 and about 40\% from fixed service charges [54]. IPART thus removed these property-based charges gradually. Instead, it imposed maximum water prices for declared water utilities that could emphasize usage charges and reflect the long-run marginal costs of water services. As a result, the annual water usage-based revenue of Sydney Water increased to about $80 \%$ of the total water revenue in 2004, while the charges based on property value ceased entirely by 1996 [55]. The profitability of the water sector has increased as the prices better reflected the costs. Sydney Water's return on assets increased to 6-8\% during 2010-2014 [56], compared to less than 3\% in the late 1990s [55]. Further, Sydney Water was able to pay a dividend of USD 189 million (about $10 \%$ of its revenue) to the NSW government in 2014 [56], while its dividend payable was USD 86 million in the early 2000s [57,58].

\subsubsection{Private Sector Participation}

Private sector participation in Sydney's water sector became more noticeable in the 2010s. In 2006, the Water Industry Competition Act (WICA) was put into practice to attract investments from private suppliers and operators in competition with Sydney Water. Private competitors can request for access to Sydney Water's infrastructures through IPART. Concurrently, Sydney Water had slowly started to outsource its water infrastructure projects. An example is the development of SDP, a monopoly supplying desalinated water under the WICA and regulated by IPART. The plant was initially funded by the NSW government, owned by Sydney Water and was constructed from 2007 to 2010 at the capital cost of USD 1352 million [59]. In 2012, the NSW government sold a 50-year lease to Sydney Desalination Plant Proprietary Limited at a price of USD 1727 million, together with a 50-year water 
supply contract with Sydney Water [59]. With the privatization of SDP, Sydney Water recouped the construction costs and made a dividend payment to the government.

\subsection{Singapore}

\subsubsection{Public Utilities Board}

The Public Utilities Board (PUB) is responsible for water management in Singapore, and this includes managing the entire water loop from rainwater collection, water production, water distribution to used water treatment [60]. It was formed on 1 May 1963 under the Ministry of Trade and Industry (MTI) to coordinate the supply of electricity, piped gas, and water for Singapore [61]. It underwent its first major institutional reform and became the national water authority in 2001, with the transfer of the sewage and drainage departments from the then Ministry of Environment to PUB [62], as a step towards integrated water management.

PUB is a wholly GOU that is organized as a statutory board under the Ministry of Environment and Water Resources (MEWR). This gives it more autonomy than being part of the ministry per se. The PUB is governed by a board of management who is appointed by panels comprising government ministers and senior civil servants and are "required to operate within the policy direction of the government and are subject to various controls exercised by the parent ministry and the central agencies of government" [63] (p. 260).

The board is currently headed by a chairman, with a chief executive Mr. $\mathrm{Ng}$ Joo Hee who oversees the Operation, Policy and Development, and Technology Divisions [64]. The Ministry's master plans and policies guide PUB's core functions. For example, the Clean Water Policy guide outlines policy aims like ensuring supply of water for all, conserving water resources, and encouraging ownership of waterways [65]. Moreover, plans like the Sustainable Singapore Blueprint 2015 outline holistic environmental policies and include many water-related issues like planning for blue spaces and water conservation [66]. Such master plans from the various ministries are important since it encourages inter-agency coordination as seen by Singapore's successful integration of land-use planning and water management [67].

Relating to regulation, PUB's operations are guided by legislative frameworks-the Public Utilities Act, the Sewerage and Drainage Act, the Environmental Protection and Management Act, and the Environmental Public Health Act [65]. These key pieces of legislation ensure that industries and private owners are under regulatory burdens to control water pollution and manage used water [67]. They provide PUB with the legislative "teeth" to regulate water resources and infrastructure in Singapore.

For example, the Public Utilities Act provides PUB with regulatory power in the management of water infrastructure and resources-ensuring the long-term sustainability of water resources in Singapore [68]. The PUB is responsible for water reclamation and the management and maintenance of the drainage system, in addition to ensuring the supply of piped water for human consumption [61]. Moreover, the act imposes various responsibilities on both the PUB and the public and ensures staff accountability for the maintenance and safety of the water facilities [61]. As a statutory board that is semi-autonomous from the government [63], PUB has a comparatively high level of autonomy.

The Board has increased water tariffs in progressive steps between 1997 and 2000, enabling the Board to generate funds for its existing infrastructure and future investment [62]. In 1997, coupled with the move by the government to levy a water conservation tax, the water tariff was readjusted to ensure a uniform flat tariff for both domestic and non-domestic users [69]. Currently, PUB adopts a water pricing formula that includes: (1) water tariff, (2) water conservation tax, and (3) waterborne fee and sanitary appliance fee [70]. Between 1995 and 2004, the average household water consumption has fallen from $21.7 \mathrm{~m}^{3}$ to $19.3 \mathrm{~m}^{3}$ [71]. 


\subsubsection{Private Sector Participation}

In the early days, decentralizing the powers of the city councils and the rural boards towards a statutory public corporation was deemed as a necessary step to improve the delivery of water utility services [72]. However, PUB has recently started engaging private companies. For example, PUB outsourced some of its major water infrastructure projects through PPPs where the design, construction, operation, and maintenance are undertaken by private operators as seen in the development of NEWater (a brand name for the reclaimed water that PUB produced) and desalination plants [60].

The tapping on the expertise of the private sector is regulated by the basic principles set out by the Singapore Ministry of Finance (MOF) which argues that PPPs enable the public sector to focus on acquiring services at the most cost-effective basis, rather than directly owning and operating the assets [73].

In 2003, the first PPP agreement in the form of a Design-Build-Own and Operate (DBOO) project for a desalination plant at Tuas was built (see Table 1). The government, as the monopoly buyer offered a tariff rate (first year water price) at 49 cents $/ \mathrm{m}^{3}$. The plant was to meet $10 \%$ of the country's potable water demand. The project was financed locally by a consortium of banks.

In 2011, a second DBOO project-a recycled water plant-was started to supply $318,500 \mathrm{~m}^{3}$ of desalinated water per day. Hyflux secured an 18-year term loan of USD 515 million to finance this plant [74]. So far, the PUB has implemented four DBOO projects-two desalination plants and two NEWater plants. A fifth DBOO project, the construction of a second NEWater Plant at Changi, which was completed in 2016 and opened in early 2017, will add another $227,300 \mathrm{~m}^{3}$ of NEWater per day to the nation's water supply.

Table 1. Private Sector participation in Tuas desalination project.

\begin{tabular}{cc}
\hline Indicators & Data \\
\hline Capital Cost & USD 143 Million \\
Concession Period & 20 years \\
Contract Ends & 2025 \\
Contract Type & Build Own Operate (BOO) \\
Tender & Open Competitive \\
Financing: Equity & USD 25 million by Hyflux (70\%) and Ondeo (30\%) \\
Financing: Debt & USD 118 million by four banks \\
Production Capacity & $136,000 \mathrm{~m}^{3} /$ day \\
Plant Type & Sea Water Reverse Osmosis (SWRO)
\end{tabular}

Source: Tiong et al. [60]. The PUB opens PPPs to international bidding, and the award of bids is on a purely competitive basis. The access to private capital is not a key consideration for the Singapore government given its relatively healthy surpluses, rather, it is the private sector's expertise that the government appears to be after [75]. Despite relatively successful PPPs, water has not been fully privatized due to the strategic and political nature of water resources [67].

The Singapore case also presents an extraordinary situation in which the private sector and the water industry as a whole benefit from the use of PPPs, where private companies own and invest in the plants and sell the water produced to the PUB, which then assumes the demand risk. This innovative use of private sector participation is discussed in the section on market-making efforts.

\subsubsection{Institutional Reform at PUB}

In 2001, the PUB, which manages Singapore's water supply, was transferred from the MTI to merge with the Sewerage and Drainage Departments in the Ministry of the Environment and Water Resources. With this reconstitution, PUB now manages the entire water loop, from the collection of rainwater from catchments, drains, canals, and ponds for storage in the reservoirs; the treatment and distribution of drinking water; the island-wide sewerage system which collects all used water for treatment; and the reclamation of used water to produce NEWater.

After the merger, the Water, Sewerage and Drainage Departments came under one roof and were encouraged to work more closely together. With NEWater, treated used water, which used to be 
discharged straight into the sea, serves a far more important function—as raw material to be reused both for drinking and for industry. In 2004, the Ministry of the Environment (ENV) was renamed MEWR to better reflect its significantly expanded role managing a strategic national resource for Singapore.

\section{Comparisons and Data}

Both cities are water-stressed with a long history of water scarcity. In terms of geography, Singapore receives twice as much rainfall as Sydney (Table 2), however, because of its small size, very little of this vast freshwater supply can be stored. We can also see that water scarcity is highly salient in Singapore, with water use half that of Sydney.

Table 2. Comparison of the two cities.

\begin{tabular}{cccc}
\hline Indicators & Units & Sydney & Singapore \\
\hline Population density, 2015 ${ }^{(1)}$ & person $/ \mathrm{km}^{2}$ & 398 & 7807 \\
Water consumption per capita ${ }^{(2)}$ & $\mathrm{m}^{3} /$ day & 293 & 153.6 \\
Long-term average annual rainfall $^{(3)}$ & $\mathrm{mm}$ & 1215.7 & 2328.7 \\
\hline
\end{tabular}

Data Source: ${ }^{(1)}$ Australian Bureau of Statistics, Greater Sydney; World Bank. ${ }^{(2)}$ Sydney Water, Water Conservation Report 2015-16 [76]; Data Government Singapore dataset, Singapore, http://bit.ly/2obeqCc. (3) Bureau of Meteorology, Australian Government; Meteorological Service Singapore, Singapore Government.

In this section, we set out to test our hypothesis that corporate governance and management play a larger role in ensuring the function of regulatory mechanisms than ownership per se. In doing so, we frame the comparison across three sections-efficiencies, fiscal prudence and expert inputs, and credible commitment in taking the politically difficult decisions. We find that although our hypothesis about the enabling nature of market-making regulations is borne out, it is not unproblematic. Efficiencies cannot always be obtained, while the politically-salient nature of water does not allow a purely technocratic logic to prevail (Nor do we think, should it).

\subsection{Efficiencies}

In this section, we use proxies of quality of service, operational, and economic efficiencies to test how both utilities measure up against each other (see Table 3). As Sydney Water and PUB operate in very different environments, a comparison between the two should be interpreted cautiously. The indicators we have chosen below, however, appear to be relatively context-independent.

Table 3. Comparison of PUB and Sydney Water.

\begin{tabular}{|c|c|c|c|c|}
\hline \multirow{2}{*}{ Indicator } & \multicolumn{2}{|c|}{ PUB } & \multicolumn{2}{|c|}{ Sydney Water } \\
\hline & 2008-2009 & 2013-2014 & 2008-2009 & 2013-2014 \\
\hline \multicolumn{5}{|l|}{ Basic Information } \\
\hline Customer accounts (million) & 1.27 & 1.36 & 4.30 & 4.80 \\
\hline Water delivered (million $\mathrm{m}^{3} /$ day) & 1.64 & 1.80 & 1.35 & 1.42 \\
\hline Asset value (million USD) & 7905 & 9477 & 11,039 & 11,555 \\
\hline Capital expenditure (million USD) & 944 & 681 & 1281 & 418 \\
\hline Operating expenditure (million USD) & 933 & 1324 & 1080 & 1103 \\
\hline \multicolumn{5}{|l|}{ Quality of Service } \\
\hline Drinking Water Quality (\%) & 100 & 100 & 99.98 & 99.99 \\
\hline Customer satisfaction (\%) & - & - & 73 & 77 \\
\hline \multicolumn{5}{|l|}{ Efficiency } \\
\hline Employees per thousand accounts & 2.46 & 2.37 & 0.73 & 0.42 \\
\hline Leakage (\%) & 5.00 & 5.00 & 7.30 & 7.30 \\
\hline Capital efficiency ( $\left.\mathrm{m}^{3} / \mathrm{USD}\right)$ & 0.64 & 0.96 & 0.38 & 1.24 \\
\hline Operating efficiency ( $\left.\mathrm{m}^{3} / \mathrm{USD}\right)$ & 0.64 & 0.50 & 0.46 & 0.47 \\
\hline
\end{tabular}

Note: All monetary quantities are expressed in current USD, considering inflation and using exchange rate data from the World Bank. The drinking water quality (\%) indicator shows how well drinking water supplied by the 
utilities meets the drinking water standards. For Sydney Water, it needs to supply drinking water that complies with the Australian Drinking Water Guidelines and NSW Health requirements. For PUB, it needs to supply drinking water that complies with the 2008 Environmental Public Health Regulations, which made the drinking water standards based on the World Health Organization Guidelines for Drinking-water Quality. Data sources: DataMonitor Industry Profiles: Water Utilities in Singapore 2011 [77]; MarketLine Industry Profiles: Water Utilities in Singapore 2015 [78]; PUB Annual Report 2014-2015 [79]; Sydney Water Annual Report Summary 2009 [80]; Sydney Water Annual Report 2014 [81]; Sydney Water Annual Report 2015-2016 [82]; Data Government Singapore dataset, http:/ / bit.ly/2obeqCc. Though both cities have a similar population, the customer accounts for Sydney Water are nearly four times as many as those for PUB in Singapore. Singapore has recently transferred the operations for industry from the government to PUB, whereas Sydney has separated the operations for industry from the wholesale and household supply. The overall water delivered by PUB in 2013-2014 was nearly 30\% higher at about 1.8 million $\mathrm{m}^{3}$ per day. This shows that water use per account is higher in Singapore-perhaps due to larger household sizes, or higher industrial water used per business account.

One area of difference in operational efficiency appears to be in leakages—Sydney Water's leakage rate is around 7.3\%, nearly 1.5 times as much as that of PUB. Globally, however, Sydney Water remains one of the top water utilities for water loss management, and achieved an Infrastructure Leak Index of 1.3 in 2013-2014 [76], reflecting best practice in the water sector across countries [83,84]. Also, Sydney Water appears to have lower average operating efficiency, which exhibited a slight increase from 2008-2009 to 2013-2014 despite the increasing operating expenditure. The operating expenditure of Sydney Water increased mainly due to the higher costs of buying bulk water and the expenses relating to SDP that were classified as capital expenditure before 2012 but considered as the operating expenditure after that. In Singapore's case, the operating efficiency of PUB decreased, mostly driven by the higher share of imported, desalinated, and recycled water-with the latter two being more capital intensive.

PUB exhibited much higher capital efficiencies than Sydney Water in 2008-2009, but Sydney Water gained greater capital efficiencies than PUB in 2013-2014. The increase of Sydney Water's capital efficiencies could also be explained to some extent by the fact that the expenses relating to SDP were not counted as a capital expenditure anymore after 2012. Lastly, though both utilities are comparable regarding the number of employees, Sydney Water has fewer employees working per thousand customer accounts-0.42 in 2013-2014 as opposed to 2.37 in PUB.

It is important to note that while the performance of PUB has been consistent over the last decade or more, the performance of Sydney Water has improved significantly during this period under the pressure of meeting the requirements of its operating license. This improvement can be reflected in the increase of capital efficiency and customer satisfaction.

\subsection{Market-Making and the Role of the Private Sector}

About market-making, the two utilities appear to have taken separate approaches. The liberalization of the sector was underwritten by regulatory changes in Sydney. To encourage market competition and private investments in the water sector, WICA established a licensing regime for new private sector providers of drinking water, recycled water, and sewerage treatment services, and a third-party access regime for them to negotiate about access to existing water and sewerage infrastructures. A private company can apply for a license to supply water or provide sewerage services using any existing water industry infrastructure. Strict licensing rules are set out to ensure that drinking water meets Australian water quality standards and that utilities deliver all services in a reliable and safe manner with minimal environmental impact [85]. By 2010, the total licenses granted under WICA included six network operator licenses and five retail supplier licenses [54]. WICA attempts to pursue equality between public and private providers by ensuring that they face similar obligations and have equal opportunities for responsibilities such as reading meters. According 
to the third-party access regime, a private applicant seeking access to infrastructure services can be granted a coverage declaration, with the right to negotiate with a service provider about terms and conditions of the access. When there are disputes, IPART is authorized to be the arbitrator. Also, IPART conducts price reviews for water, sewerage and storm-water services of Sydney Water every four years. These price reviews provide valuable information on pricing development in the water industry for new private entrants. Though Sydney Water continues to be a major supplier of water and water services, private sector participation in the water industry serves largely as an impetus to encourage Sydney Water to deliver better performance.

As part of the market-making measures, regulation was put in place to address customer engagement in water supply and sewage services. Under WICA, customers' rights are safeguarded by provisions, allowing customers to transfer from one licensed retail supplier to another [85]. In the operating license, IPART specifically requires Sydney Water to recognize the rights of customers [51]. Further, IPART is increasingly making customer participation a focal point in the regulatory process. For instance, IPART has established guidelines for customer engagement in price reviews for regulated water businesses and is planning to engage customers in determining water prices in future price reviews [86].

With the pressures of meeting system performance regulations, environmental protection standards, and customer service expectations, Sydney Water invested USD 4.8 million during 2015-2016 in more than 30 Research and Development projects [82]. Further, Sydney Water plans to spend USD 542 million on capital works programs in 2016-2017, covering asset renewal and rehabilitation, water and wastewater infrastructure improvement, and information or energy saving projects [82]. To involve customers in service and decision-making processes, Sydney Water operates the Customer Council, which consists of members from residential consumers, people living in rural and urban fringe areas, business and consumer groups and organizations representing low-income households.

In Sydney, therefore, the role of regulation and the regulator was to create a retail market for water and to increase consumer choice through a new regulatory architecture.

In Singapore, a raft of regulation was also put in place to create new markets, but in this case, the market was that of water as a business, rather than Australia's consumer-centric approach. In 2006, the Government made the commitment to grow three sectors of its economy-biomedical sciences, environment and water technologies, and multi-media. Water was one of the key areas, and Singapore set up the Environment \& Water Industry Programme Office (EWI) to spearhead efforts to develop the environment and water industry. Today, the offices regulate about USD 336 million in funding from the National Research Foundation. Regarding market-making, the EWI aims to grow value-added contributions from the water sector increasing from USD 475 million $(0.3 \%$ of the gross domestic product, GDP) in 2003 to USD 1216 million (0.6\% of GDP) by 2015, and double employment in the water industry to 11,000 persons.

PUB appears to have achieved this-today, the industry contributes USD 1073 million to Singapore's GDP and has created 12,400 jobs so far. The PUB positions itself as a committed custodian of water resources in Singapore, as well as a willing investor in water infrastructure and technologies. From 2006 to 2012, Singapore-based water companies bagged over 100 international projects worth more than USD 7156 million.

\subsection{Credible Commitment: Analysis of Price Increases}

In Sydney, IPART regulates water pricing, with the consideration of customer protection against monopolies and promoting competition in the water sector. Every four years, IPART reviews the price of water and water services provided by Sydney Water and determines the price for the next four years. Also, IPART works on restructuring water and water service prices so as to remove inequities between customer groups and enhance the cost-reflectivity of prices. For instance, in the price reviews for Sydney Water in 2012, IPART pointed out that the current price structures of water 
usage and services still had cross-subsidies between customer groups, which led to some customers being unfairly charged more for the same services [87]. To solve this problem, IPART introduced a standard water service charge for all residential customers, regardless of the type of property where they were living. In addition, IPART claimed that over the recent determination period (2012-2016), the charges $\left(\mathrm{USD} / \mathrm{m}^{3}\right.$ ) for drinking water usage would not change (see Table 4), but the fixed service charges (USD per year) would decrease. As a result of these reforms, some residential customers would experience reductions in their annual water bills, while others would experience increases or no change in the bills during the determination period.

Customer service has been a performance measure in annual reports of the regulated water utility corporations under IPART. Water utility corporations obtain credibility through enhancing customer relation with better technologies, convenient billing management, and financial assistance. For instance, Sydney Water provides various financial services (e.g., payment assistance and advice) to help customers with financial difficulties.

While Sydney's case shows how solid political and public support can legitimize price increases, we find in the Singapore case that historical context can also play a significant role.

The issue of water between Malaysia and Singapore has always been highly contentious. Singapore has been importing water from Malaysia since 1927 in an agreement between the municipal commissioners of the town of Singapore and Sultan Ibrahim of the state and territories of Johor. The Singapore city council and Johor state government signed two other water agreements in 1961 and 1962. The 1961 Water Agreement with the State of Johor in Malaysia ensured that Singapore had the "full and exclusive right and liberty to take, impound and use all the water" within the Gunong Pulai and Pontian catchments, and Tebrau and Scudai Rivers, up till 2011. In 1962, a separate Water Agreement was arranged which enables Singapore to draw and use up to 1.13 million $\mathrm{m}^{3}$ of water from the Johor River until 2061 [88].

In December 1998, Malaysia raised the issue of price revisions. After a meeting in Hanoi, the Prime Ministers of both countries agreed to tackle the water issue as a part of a package of bilateral issues. By 1999, despite three top-level meetings, there was little progress. In the early 2000s, Malaysia itself was running dry and faced the prospect of water rationing. This led to a heated demand from its people that water should go to Malaysians before being sold to Singapore [89].

Table 4. Water price comparison between Sydney and Singapore.

\begin{tabular}{|c|c|c|c|c|c|c|c|c|c|c|c|c|}
\hline Water Price & 1995 & 2000 & 2004 & 2007 & 2008 & 2009 & 2010 & 2011 & 2012 & 2013 & 2014 & 2015 \\
\hline $\begin{array}{l}\text { Singapore Average } \\
\text { Price }\left(\mathrm{USD} / \mathrm{m}^{3}\right)\end{array}$ & 0.48 & 1.08 & 1.09 & 1.09 & 1.09 & 1.09 & 1.09 & 1.09 & 1.09 & 1.09 & 1.09 & 1.09 \\
\hline $\begin{array}{c}\text { Sydney Average Price } \\
\left(\mathrm{USD} / \mathrm{m}^{3}\right)\end{array}$ & $1.91 *$ & 1.51 * & $1.89 *$ & 1.38 & 1.61 & 1.80 & 1.90 & 2.10 & 2.10 & 2.10 & 2.10 & 2.10 \\
\hline
\end{tabular}

Data Source: water price of Sydney is mainly from reports of IPART [87,90,91]. * denotes data from a report of Sydney Water Corporation [76]. Water price of Singapore is from Tortada [71].

Given this sense of crisis, the increase in tariffs at the time was passed with little opposition. However, despite the language that Singapore is charging water to the "marginal price" of the next drop, there are significant subsidies for water today. From Parliamentary records, in 2011, PUB collected USD 482 million in tariffs. From the waterborne fee and the sanitary appliance fee, it collected about USD 233 million. Yet the total spending on water-related expenditure was USD 930 million.

Given the difficulty in raising prices, we see that water pricing remains a highly political and challenging issue in Singapore. However, because of the nature of the PPP in Singapore, as long as the government retains its strong financial position as a monopoly buyer, there is no eroding of its credibility vis-à-vis the private sector. 


\section{Conclusions}

From our comparison of the two cases, we have seen that while the reforms in Sydney have resulted in significant improvement in the functioning of Sydney Water, comparable efficiencies have been achieved by PUB without an independent regulator. What matters more for a GOU is the system and nature of regulations rather than the existence of an independent regulator. At the same time, we see that with regards to investments and attracting private sector players, the role of the regulator has been used to promote a more active retail market for water in Sydney. Singapore could potentially benefit from an increase in choices, but this could come at the cost of lower capital efficiency. At the same time, given its relatively smaller as well as denser population, what it gains in freedom of choice and competition may be lost by way of economies of scale. Lastly, the use of the regulatory state device of credible commitment does not appear to operate very powerfully in Singapore. Paradoxically, the strong financial position of the government makes it hard for it to raise water tariffs, which are currently below cost-recovery. The government has recently announced a rise in tariff by 30 per cent starting from 1 July 2017 [92], without much public consultation. The response, unsurprisingly, was great public unhappiness. In contrast, Sydney appears to have had more success with raising water prices after the regulator was introduced (Table 4). Here, the regulator seems to have played a vital role in ensuring the financial viability of Sydney Water and slowly changing citizen perceptions about pricing water. In fact, the active customer representation in the determining of water charges in the country can be considered as a success of the regulator in communicating the trade-offs between quality of service and water prices to the consumer and eliciting their priorities on regulation. As a policy recommendation, therefore, it may be useful for Singapore to consider instituting some form of customer representation in service and decision-making processes such as Sydney Water's Customer Council.

Acknowledgments: This work was supported by a Start-up Grant WBS (R-603-000-220-133), Lee Kuan Yew School of Public Policy, National University of Singapore.

Author Contributions: Ching Leong conceived of the theoretical motivations and designed the research; Lili Li carried out the part of the research relating to Sydney. Both contributed to the writing of the paper.

Conflicts of Interest: The authors declare no conflict of interest.

\section{References}

1. Kingdom, B.; Liemberger, R.; Marin, P. The Challenge of Reducing Non-Revenue Water in Developing Countries-How the Private Sector Can Help: A Look at Performance-Based Service Contracting; World Bank: Washington, DC, USA, 2006.

2. Komives, K.; Halpern, J.; Foster, V.; Wodon, Q. The Distributional Incidence of Residential Water and Electricity Subsidies; World Bank: Washington, DC, USA, 2006.

3. Wang, H.; Wu, W.; Zheng, S. An Econometric Analysis of Private Sector Participation in China's Urban Water Supply. Util. Policy 2011, 19, 134-141. [CrossRef]

4. Lo Storto, C. Are Public-Private Partnerships a Source of Greater Efficiency in Water Supply? Results of a Non-Parametric Performance Analysis Relating to the Italian Industry. Water 2013, 5, 2058-2079. [CrossRef]

5. Suárez-Varela, M.; de Los Ángeles García-Valiñas, M.; González-Gómez, F.; Picazo-Tadeo, A.J. Ownership and Performance in Water Services Revisited: Does Private Management Really Outperform Public? Water Resour. Manag. 2017, 31, 2355-2373. [CrossRef]

6. Gassner, K.; Popov, A.; Pushak, N. An Empirical Assessment of Private Sector Participation in Electricity and Water Distribution in Developing and Transition Counties; World Bank Working Paper; World Bank: Washington, DC, USA, 2007.

7. Romano, G.; Molinos-Senante, M.; Guerrini, A. Water Utility Efficiency Assessment in Italy by Accounting for Service Quality: An Empirical Investigation. Util. Policy 2017, 45, 97-108. [CrossRef]

8. Estache, A.; Kouassi, E. Sector Organization, Governance, and the Inefficiency of African Water Utilities; Governance, Regulation, and Finance Division, World Bank: Washington, DC, USA, 2002. 
9. Lannier, A.L.; Porcher, S. Efficiency in the Public and Private French Water Utilities: Prospects for Benchmarking. Appl. Econ. 2014, 46, 556-572. [CrossRef]

10. Romano, G.; Guerrini, A.; Vernizzi, S. Ownership, Investment Policies and Funding Choices of Italian Water Utilities: An Empirical Analysis. Water Resour. Manag. 2013, 27, 3409-3419. [CrossRef]

11. Romano, G.; Guerrini, A. The Effects of Ownership, Board Size and Board Composition on the Performance of Italian Water Utilities. Util. Policy 2014, 31, 18-28. [CrossRef]

12. Hon, L.Y.; Boon, T.H.; Lee, C. Productivity, Efficiency, and Privatization in the Malaysian Water Industry. J. Southeast Asian Econ. 2014, 31, 292-312. [CrossRef]

13. Estache, A.; Perelman, S.; Trujillo, L. Infrastructure Performance and Reform in Developing and Transition Economies: Evidence from a Survey of Productivity Measures; World Bank Policy Research Working Paper (3514); World Bank: Washington, DC, USA, 2005.

14. Vinnari, E.M. The Economic Regulation of Publicly Owned Water Utilities: The Case of Finland. Util. Policy 2006, 14, 158-165. [CrossRef]

15. Renzetti, S.; Dupont, D. Ownership and Performance of Water Utilities. Greener Manag. Int. 2003, 42, 9-19. [CrossRef]

16. Cowan, S. Welfare Consequences of Tight Price-cap Regulation. Bull. Econ. Res. 1998, 50, 105-116. [CrossRef]

17. Sawkins, J.W. The Development of Competition in the English and Welsh water and Sewerage Industry. Fisc. Stud. 2001, 22, 189-215. [CrossRef]

18. Zerbe, R.O.; McCurdy, H.E. The Failure of "Market Failure". J. Policy Anal. Manag. 1999, 18, 558-578. [CrossRef]

19. Geddes, R.R. A Historical Perspective on Electric Utility Regulation. Regulation 1992, 15, 1-65.

20. Berg, S.V. Best Practices in Regulating State-Owned and Municipal Water Utilities; Economic Commission for Latin America and the Caribbean (ECLAC)_Project Documents Collection; Economic Commission for Latin America and the Caribbean: Santiago, Chile, 2013.

21. Mukhtarov, F. Rethinking the Travel of Ideas: Policy Translation in the Water Sector. Policy Politics 2014, 42, 71-88. [CrossRef]

22. Mukhtarov, F.; Daniell, K.A. Transfer, Diffusion, Adaptation, and Translation of Water Policy Models. In The Oxford Handbook of Water Politics and Policy; Conca, K., Weinthal, E., Eds.; Oxford University Press: England, UK, 2016; pp. 1-29. [CrossRef]

23. Menozzi, A.; Urtiaga, M.G.; Vannoni, D. Board Composition, Political Connections, and Performance in State-Owned Enterprises. Ind. Corp. Chang. 2012, 21, 671-698. [CrossRef]

24. Beecher, J.A. What Matters to Performance? Structural and Institutional Dimensions of Water Utility Governance. Int. Rev. Appl. Econ. 2013, 27, 150-173. [CrossRef]

25. Berg, S.; Marques, R. Quantitative Studies of Water and Sanitation Utilities: A Benchmarking Literature Survey. Water Policy 2011, 13, 591-606. [CrossRef]

26. Hutton, G.; Bartram, J. Global Costs of Attaining the Millennium Development Goal for Water Supply and Sanitation. Bull. World Health Organ. 2008, 86, 13-19. [CrossRef] [PubMed]

27. Marin, P. Public-Private Partnerships for Urban Water Utilities: A Review of Experiences in Developing Countries; World Bank: Washington, DC, USA, 2009.

28. Megginson, W.L.; Netter, J.M. From State to Market: A Survey of Empirical Studies on Privatization. J. Econ. Lit. 2001, 39, 321-389. [CrossRef]

29. Bremer, J. Creative Public-private Partnerships Needed, not Misleading Rhetoric. Water Wastewater Int. 2003, 18, 11-13. Available online: http://www.waterworld.com/articles/wwi/print/volume-18/issue1/editorial-focus/creative-public-private-solutions-needed-not-misleading-rhetoric.html (accessed on 15 June 2017).

30. Prasad, N. Privatisation Results: Private Sector Participation in Water Services after 15 Years. Dev. Policy Rev. 2006, 24, 669-692. [CrossRef]

31. Spronk, S. Roots of Resistance to Urban Water Privatization in Bolivia: The "New Working Class", the Crisis of Neoliberalism, and Public Services. Int. Labor Work. Hist. 2017, 71, 8-28. [CrossRef]

32. Robbins, P.T. Transnational Corporations and the Discourse of Water Privatization. J. Int. Dev. 2003, 15, 1073-1082. [CrossRef]

33. De Gouvello, B.; Scott, C.A. Has Water Privatization Peaked? The Future of Public Water Governance. Water Int. 2012, 37, 87-90. [CrossRef] 
34. Valdovinos, J. The Remunicipalization of Parisian Water Services: New Challenges for Local Authorities and Policy Implications. Water Int. 2012, 37, 107-120. [CrossRef]

35. Braithwaite, J.; Coglianese, C.; Levi-Faur, D. Can Regulation and Governance Make a Difference? Regul. Gov. 2007, 1, 1-7. [CrossRef]

36. Jarvis, D.S.L.; Sovacool, B.K. Conceptualizing and Evaluating Best Practices in Electricity and Water Regulatory Governance. Energy 2011, 36, 4340-4352. [CrossRef]

37. Majone, G. The regulatory state and its legitimacy problems. West Eur. Polit. 1999, 22, 1-24. [CrossRef]

38. Scott, C. Regulation in the Age of Governance: The Rise of the Post- Regulatory State. In The Politics of Regulation: Institutions and Regulatory Reforms for the Age of Governance; Jordana, J., Levi-Faur, D., Eds.; Edward Elgar Publishing: Cheltenham, UK, 2003.

39. Salamon, L.M. The Tools of Government: A Guide to the New Governance; Oxford University Press: Oxford, UK, 2002.

40. Hood, C.; James, O.; Jones, G.; Scott, C.; Travers, T. Regulation Inside Government; Oxford University Press: Oxford, UK, 1999.

41. Levi-Faur, D. The Global Diffusion of Regulatory Capitalism. Ann. Am. Acad. Pol. Soc. Sci. 2005, 598, 12-32. [CrossRef]

42. Banfield, E.C. Corruption as a Feature of Governmental Organization. J. Law Econ. 1975, 18, 587-605. [CrossRef]

43. Halvorsen, T.; Hauknes, J.; Miles, I.; Røste, R. On the Differences between Public and Private Sector Innovation; Report No. 9. PUBLIN; European Social Innovation Research: Oslo, Norway, 2005.

44. Bakker, K. From Public to Private to...Mutual? Restructuring Water Supply Governance in England and Wales. Geoforum 2003, 34, 359-374. [CrossRef]

45. Australian Bureau of Statistics. Greater Sydney: Region Data Summary. Available online: http:/ / stat.abs.gov.au/itt/r.jsp?RegionSummary\&region=1GSYD\&dataset=ABS_REGIONAL_ASGS\& geoconcept=REGION\&measure=MEASURE\&datasetASGS=ABS_REGIONAL_ASGS\&datasetLGA=ABS_ REGIONAL_LGA\&regionLGA=REGION\&regionASGS=REGION (accessed on 14 August 2016).

46. North, M. Water, Dictionary of Sydney. 2011. Available online: http://dictionaryofsydney.org/entry/water (accessed on 14 August 2016).

47. Sydney Morning Herald. A City Busting to Go-into the Ocean. 2003. Available online: http:/ /www.smh. com.au/articles/2003/08/04/1059849343872.html (accessed on 14 August 2016).

48. NSW Legislation. Sydney Water Act 1994 No. 88. Updated on 10 January 2012 on the NSW Legislation Website; 2012. Available online: http:/ / www.legislation.nsw.gov.au/inforcepdf/1994-88.pdf?id=a1f77bd814d5-e722-8119-e1abecea1bbb (accessed on 14 August 2016).

49. Sydney Water. Board Members. Available online: http://www.sydneywater.com.au/SW/about-us/ourorganisation/who-we-are/board-members/index.htm (accessed on 14 August 2016).

50. Independent Pricing and Regulatory Tribunal (IPART). About IPART. Independent Pricing and Regulatory Tribunal: Sydney, Australia, 2016. Available online: http:/ /www.ipart.nsw.gov.au/Home/For_Consumers / About_IPART (accessed on 14 August 2016).

51. Independent Pricing and Regulatory Tribunal (IPART). Sydney Water Corporation Operating Licence 2015-2020; Independent Pricing and Regulatory Tribunal: Sydney, Australia, 2015.

52. Independent Pricing and Regulatory Tribunal (IPART). Sydney Water Corporation Reporting Manual; Independent Pricing and Regulatory Tribunal: Sydney, Australia, 2015.

53. Groom, E. Case Study on Water Regulation in Australia: Sydney Water; Presentation by IPART; World Bank Workshop on Water Regulation for MENA: Marseille, France, 2015; Available online: http:/ /www. cmimarseille.org/highlights/workshop-regulating-water-services-provision-mena (accessed on 14 August 2016).

54. Cox, J. IPART's Approach to Urban Water Pricing in NSW. In Proceedings of the Australian Agricultural and Resource Economics Society Annual Conference, Adelaide, Australia, 1 October 2010; Available online: http:/ / www.aares.org.au/CMDownload.aspx?ContentKey=b406d79c-d009-4257-ae24de3d23f204f2\&ContentItemKey=2f9f0529-a3cb-4106-8d7e-ea16a2b176ac (accessed on 14 August 2016).

55. Sydney Water. Sydney Water Annual Report 2004: Environmental, Social and Economic Performance; Sydney Water: Sydney, Australia, 2004.

56. Sydney Water. Sydney Water Annual Report 2014-15; Sydney Water: Sydney, Australia, 2015. 
57. Sydney Water. Sydney Water Annual Report 2002; Sydney Water: Sydney, Australia, 2002.

58. Sydney Water. Sydney Water Annual Report 2003: Environmental, Social and Economic Performance; Sydney Water: Sydney, Australia, 2003.

59. Sydney Desalination Plant. Our History, Sydney Desalination Plant. Available online: http://www. sydneydesal.com.au/who-we-are/our-history/ (assessed on 14 August 2016).

60. Tiong, R.L.K.; Sha, Z.; Chowdhury, A.N. Development of Public-private Partnerships in the Water Sector in Singapore. In Water Governance: An Evaluation of Alternative Architectures; Gunawansa, A., Bhullar, L., Wong, A., Tiong, R.L.K., Zheng, S., Chowdhury, A.N., Eds.; Edward Elgar: Cheltenham, UK, 2013; pp. 242-261.

61. Tortajada, C.; Joshi, Y.K. Water Quality Management in Singapore: The Role of Institutions, Laws and Regulations. Hydrol. Sci. J. 2014, 59, 1763-1774. [CrossRef]

62. PUB. "The PUB Brand", Public Utilities Board, Government of Singapore. 2016. Available online: https://www.pub.gov.sg/about/thepubbrand (accessed on 10 January 2017).

63. Jones, D.S. Financial Reforms of Statutory Bodies in Singapore: Control and Autonomy in a Centralized State. Public Organ. Rev. 2006, 6, 259-276. [CrossRef]

64. PUB. "PUB Organization Chart", Public Utilities Board, Government of Singapore. 2016. Available online: https://www.pub.gov.sg/about/organisationalchart (accessed on 10 January 2017).

65. MEWR. MEWR I Managing Our Water. 2015. Available online: http://www.mewr.gov.sg/policy/managingour-water\#verticalTab1 (accessed on 10 January 2017).

66. Sustainable Singapore Blueprint 2015; Ministry of Environment and Water Resources Singapore: Singapore, 2015.

67. Luan, I.O.B. Singapore Water Management Policies and Practices. Int. J. Water Resour. Dev. 2010, 26, 65-80. [CrossRef]

68. Government of Singapore. Public Utilities Act, Chapter 261, Singapore Statues Online, Government of Singapore. 2001. Available online: http://statutes.agc.gov.sg/aol/search/display/view.w3p;page=0;query= DocId\%3A138d92b9-9a21-4649-b14d-97552a8af9a1\%20Depth\%3A0\%20Status\%3Ainforce;rec=0 (accessed on 10 January 2017).

69. Khoo, T.C. Singapore Water: Yesterday, Today and Tomorrow. In Water Management in 2020 and Beyond; Biswas, A.K., Tortajada, C., Izquierdo-Avino, R., Eds.; Springer: London, UK, 2009; pp. 237-250.

70. PUB. Water Tariff, Public Utilities Board, Government of Singapore. Available online: https://www.pub.gov. sg/watersupply/watertariff (accessed on 12 January 2017).

71. Tortajada, C. Water Management in Singapore. Int. J. Water Resour. Dev. 2006, 22, 227-240. [CrossRef]

72. Board Will Run Water, Light and Electricity. NewspaperSG; 26 January 1956; p. 1. Available online: http://eresources.nlb.gov.sg/newspapers/Digitised/Article/freepress19560126-1.2.10?ST=1\&AT= search\&k=Board\%20Will\%20Run\%20Water,\%20Light\%20and\%20Electricity\&QT=board, will,run,water, light, and,electricity\&oref=article (accessed on 15 June 2017).

73. Ministry of Finance. Public Private Partnership Handbook, 2nd ed.; Ministry of Finance: Singapore, 2012. Available online: www.mof.gov.sg/Portals/0/Policies/ProcurementProcess/PPPHandbook2012.pdf (accessed on 24 February 2017).

74. Hyflux. PUB and Hyflux Officially Open Singapore's Second and Largest Desalination Project. 13 September 2013. Available online: http://investors.hyflux.com/newsroom/20130918_190104_600_ 6147CE41D66B86FA48257BE900286DFC.1.pdf (accessed on 12 January 2017).

75. Low, J. Sustaining the Value of Water. In Case Studies in Public Governance: Building Institutions in Singapore; Gwee, J., Ed.; Routledge: London, UK, 2012; pp. 94-120.

76. Sydney Water. Water Conservation Report 2015-16; Sydney Water: Sydney, Australia, 2016.

77. DataMonitor Industry Profiles. Water Utilities in Singapore; DataMonitor: London, UK, 2011; Available online: http:/ / marketsensus.com/water-utilities-in-singapore-3 (accessed on 24 February 2017).

78. MarketLine Industry Profiles. Utilities in Singapore; Alacra Store: New York, NY, USA, 2015; Available online: http:/ / www.alacrastore.com/storecontent/MarketLine-Industry-Profiles/Utilities-in-Singapore2124-420 (accessed on 24 February 2017).

79. PUB. PUB Annual Report 2014-15; Public Utilities Board: Singapore, 2015.

80. Sydney Water. Sydney Water Annual Report Summary 2009; Sydney Water: Sydney, Australia, 2009.

81. Sydney Water. Sydney Water Annual Report 2014; Sydney Water: Sydney, Australia, 2014. 
82. Sydney Water. Sydney Water's Annual Report 2015-2016; Sydney Water: Sydney, Australia, 2016.

83. Winarni, W. Infrastructure Leakage Index (ILI) as Water Losses Indicator. Civ. Eng. Dimens. 2009, 11, $126-134$.

84. Seago, C.J.; Mckenzie, R.S.; Liemberger, R. International Benchmarking of Leakage from Water Reticulation Systems. In Proceedings of the IWA Specialised Conference "Leakage 2005", Halifax, NS, Canada, 12-14 September 2005; pp. 1-14.

85. NSW Office of Water. Water Industry Competition; Private Water Industry, NSW Office of Water: Sydney, Australia, 2016. Available online: http:/ /www.water.nsw.gov.au/urban-water/private-water-industry/ water-industry-competition (assessed on 10 January 2017).

86. Independent Pricing and Regulatory Tribunal (IPART). Customer Engagement on Prices for Monopoly Services; Independent Pricing and Regulatory Tribunal: Sydney, Australia, 2012.

87. Independent Pricing and Regulatory Tribunal (IPART). Review of Prices for Sydney Water Corporation's Water, Sewerage, Storm-Water and Other Service from 1 July 2012; Independent Pricing and Regulatory Tribunal: Sydney, Australia, 2012.

88. Ministry of Foreign Affairs Singapore. Special Events: Water. Available online: https://www.mfa.gov.sg/ content/mfa/media_centre/special_events/water.html (accessed on 24 February 2017).

89. Ministry of Information, Communications and the Arts. Water Talks? If Only It Could; Ministry of Information, Communications and the Arts: Singapore, 2003; p. 3.

90. Independent Pricing and Regulatory Tribunal (IPART). Investigation into Prices for Water, Sewerage and Storm-Water Services Provided by Sydney Water Corporation-From 1 July 2008; Independent Pricing and Regulatory Tribunal: Sydney, Australia, 2008.

91. Independent Pricing and Regulatory Tribunal (IPART). Sydney Water Corporation: Prices of Water Supply, Wastewater and Stormwater Services from 1 July 2003 to 30 June 2005; Independent Pricing and Regulatory Tribunal: Sydney, Australia, 2003.

92. PUB. Water Price. Available online: https://www.pub.gov.sg/watersupply/waterprice (accessed on 21 April 2017).

(C) 2017 by the authors. Licensee MDPI, Basel, Switzerland. This article is an open access article distributed under the terms and conditions of the Creative Commons Attribution (CC BY) license (http:/ / creativecommons.org/licenses/by/4.0/). 